\title{
Plant Pathology Introduction
}

\author{
Teena Agrawal* \\ Department of Plant Genecology, Banasthali University, India
}

Submission: March 19, 2018; Published: May 21, 2018

"Corresponding author: Teena Agrawal, University of Banasthali, Assistant professor, Department of Plant Genecology, Niwai, India, Tel: 9680724243; E-mail: tagrawal02@gmail.com

\begin{abstract}
Plant pathology is the sciences of integration of the botanical sciences and the diseases of plant and there control. The sciences of the plant pathology are very valuable and they are responsively for the growth of the crops in the good ways, since the plant pathogens are responsible for the major epidemic and the major losses of the crops. Here in this review article we have presented some of the aspects of the plant pathology and there history. The articles are very valuable for the students of the plant pathology.
\end{abstract}

Keywords: Plant pathology; Valuable; Informative; Crops

\section{Introduction}

Plant pathology is the sciences which is concerned with the detailed study of the plant diseases and there chemical control, the plant diseases always cause the devastating effects and they are responsible for the changes the culture and there ways for the living plant diseases are the result of the unfavourable environment condition and the interaction of the pathogen negatively. The branches of the plant pathology are very valuable and they are used for the protecting of the many kinds of the food crops an civilization as well as the cereals crops for the several kinds of the beneficiation [1]. It is estimated that the dieses together form the and they are responsible for the annual loss of the many crops of the economic crops such as the fruits and the vegetables and the many of the cereal crops and the other kinds of the pulses and the many kinds of the food crops [2] generally annually in the India as well as the countries like the USA and the other European countries the plant diseases are responsible for the damage for the annual loss of the $38-40 \%$ diseases plant forms the very valuable and the important part of the earth economy and they are the basis of the many kind of the ecosystem and there life cycles, the earth basic biogeochemical cycles are based on the interaction of the plants worth the environment.

All parts of the plant such as the leaves, fruits and the seeds and the stem are very valuable and they are utilised for the several purposes for the fulfilment of the various kind of the needs of the humans bong in the different civilizations as well as the world. Even the food which comes from the animals also comes from the animals which indirectly depend on the plants for their diet and their basic needs [3]. In nature the plants are the only higher organism which converts the light emery into the chemical energy and they forms the differ kinds of the metabolites of the various significances. in the plant several kinds of the agents causes the diseases, theses are as similar to the other kinds of the microorganism as in the human beings like the fungi, bacteria, viruses, protozoa and the nematode, fungi cause a large amount of the portion of the microorganisms which causes the several diseases and they are responsible for the development of the era of plant pathogens and the literature [4].

Plant pathology is the study of the interaction of the organisms as well as the environment, which causes the diseases. It also includes the methods for the preventing of the plants diseases for the various purposes. plants are the basis of the life and they are responsible for the food as well as the medicines, so the diseases of the fungi and the plant pathology always causes the devastating effects and they needs the different methods for the saving of the plants for the various purposes plant pathology is the integrative sciences, it is the culmination of the many kinds of the branches like the botany, mycology, fungal biology, virology, nematology, plant physiology, genetics, the molecular biology, tissue culture, soil sciences, forestry, agronomy, meteorology and many other branches of the sciences [1,5]. Plant pathology provides the means for the complete aspects of the plant diseases as well as it provides the way for the solution of the treatment of the diseases by the various means $[1,6]$. Uncontrolled plant diseases always was the ways for the reduced growth of the plants and their products and the sometimes the complete eradication of the plants from that area. Sometimes they effects the beauty of the landscape and the places and they are responsible for the complete eradication of the existing civilization form that area, there are several examples of the plant disuses which has causes the several devastating effects and they destroy the culture growth of the area. Diseases plants are responsible for the human diseases [1]. 
In the last 100 years the plant diseases are controlled by the chemical weapons like the differ kinds of the herbicides and the fungicides and the heavy toxic chemicals. Controlling of the plant pathogens is the to only form the superficial aspects but also from the soil so that they can eradicate the plant pathogens completely form the soil. However the heavy chemicals are very dangerous for the growth of the crops, so they need the more effective and biologically safe methods for the controlling of the diseases. The biological methods are very safe and they eradicate the pathogens by the means of roots and they eradicate the pathogens by the eco friendly manners. The major methods for the controlling of the diseases are limited to the uses for the antagonistic methods of the controlling of the dieses and the many kinds of the plant breeding approaches as well as the many new genetic engineering methods for the controlloning of the dieses [1].

The diseases plants are unhealthy and they are not able to function well in any means like the ant metabolic process is hindered and the plant works in unhealthy way the symptoms of the indexed and the unhealthy plants are varies from the short to the very large kinds, like sometimes the dieses are localised and they appears in the forms of the short spot and in the forms of the necrotic tissue and sometimes they changes the complete morphology of the concerned plants and they damage the plants form the roots to the top dieses in the plant is the any invisible and the visible changes in the cells as well as in the tissues, due to the environmental and the pathogen interaction, which are responsible for the death of the concerned tissues as well as the other part of the plant, which leads to the death of the plant or the crops any effected part of the plants such as the roots are also becomes rotten and they are responsible for the severe damage of the roots, the roots makes them unable for abortion of the metabolites and the water from the soil, infection of the xylem vessels leads to the plugging of the xylem vessels and they cause the bogging the vessels so that translocation of the food and the metabolites becomes hampers. Infection of the eaves leads to the formation of the spots, blights, rusts and mildews, moscaces and they interfere with the photosynthesis. infection in the phloem cell leads to the plugging of the phloem cells and they leads to the cankers, amy of the samla microorganism like the viruses, molecules and the Protozoa are he pathogens which plugs the sites of the phloem's .

Infected cells almost dies, infected cells results in the formation of the hyperplasia and the hypertrophy. Which turns in to the abnormal growth which leads to the formation of the many kinds of the galls form the minute kinds to the large one gale which appears very large and they disjunction the plant completely [1]. Pathogenic micro organism generally disturbs the plants by interfering the formation of the enzymes and toxins and the greet regulators, some pathogens grows and they multiplying the vessels of the xylem and they plugged the companion cells of the phloem and they interfere the normal functioning of the vascular tissues. Environmental factors are also responsible for the propagation of the diseases and the perpetuation of the dieses in the field [1] (Figure 1).

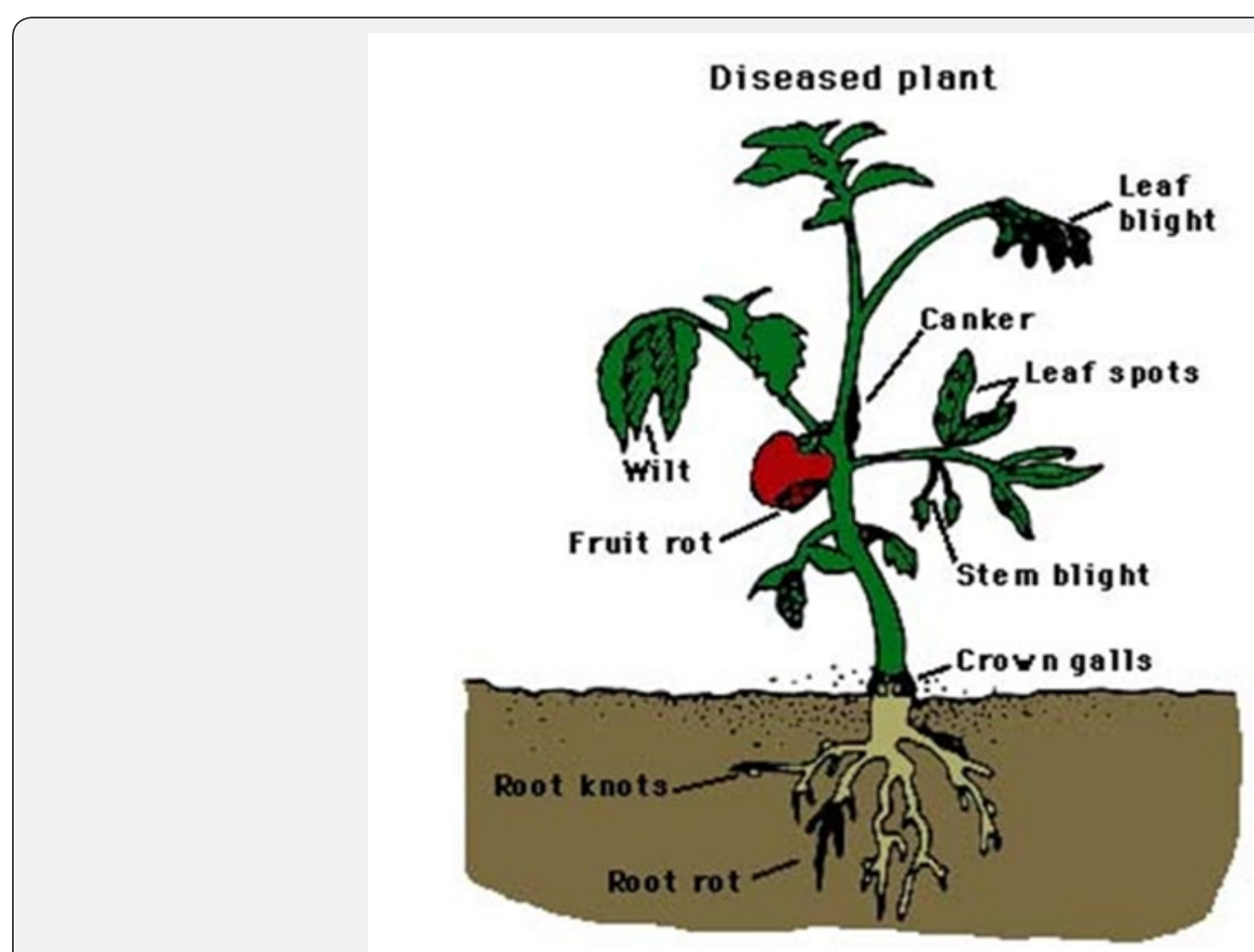

Figure 1: Possible disease symptoms on plants. 


\section{Different Types of the Plant Diseases}

From low to the several kinds of the plant pathogenic diseases results in the infection of the crops from the roots to the top of the tree or the crops. These crops affect the cultivated as well as the many kinds of the wild types of the plants. An each kinds of the crop plants can be affected by the form few to the several thousand types of the plant pathogens. Plant dieses have been grouped by the many ways, like on the basis of the symptoms spots, blights, rusts and the smuts, rots, wilts or some times on the basis of the plant organ they effects like the roots diseases, stem diseases, foliage diseases, or sometimes they have classified as the on the basis of the plant they effected like the turf diseases vegetable dieses and the crop diseases [1]. Plants are dieses by the several means like they are affected by the way of the biotic agents and the sometimes they are affected by the a biotic methods, so the classification of the diseases on the basis of the agents have been done like this

a) Infectious diseases or the diseases by the biotic means: Diseases caused by the fungi, diseases caused by the prokaryotes, diseases caused by the viruses and the viroids, diseases caused by the nematodes. Diseases caused by the protozoa.

b) Diseases caused by the various a biotic means:

Like the ph, drought, salinity and the pressures and the different kinds of the population, nutrition deficiencies mineral toxicities, diseases by the soil acidity (Figure 2).

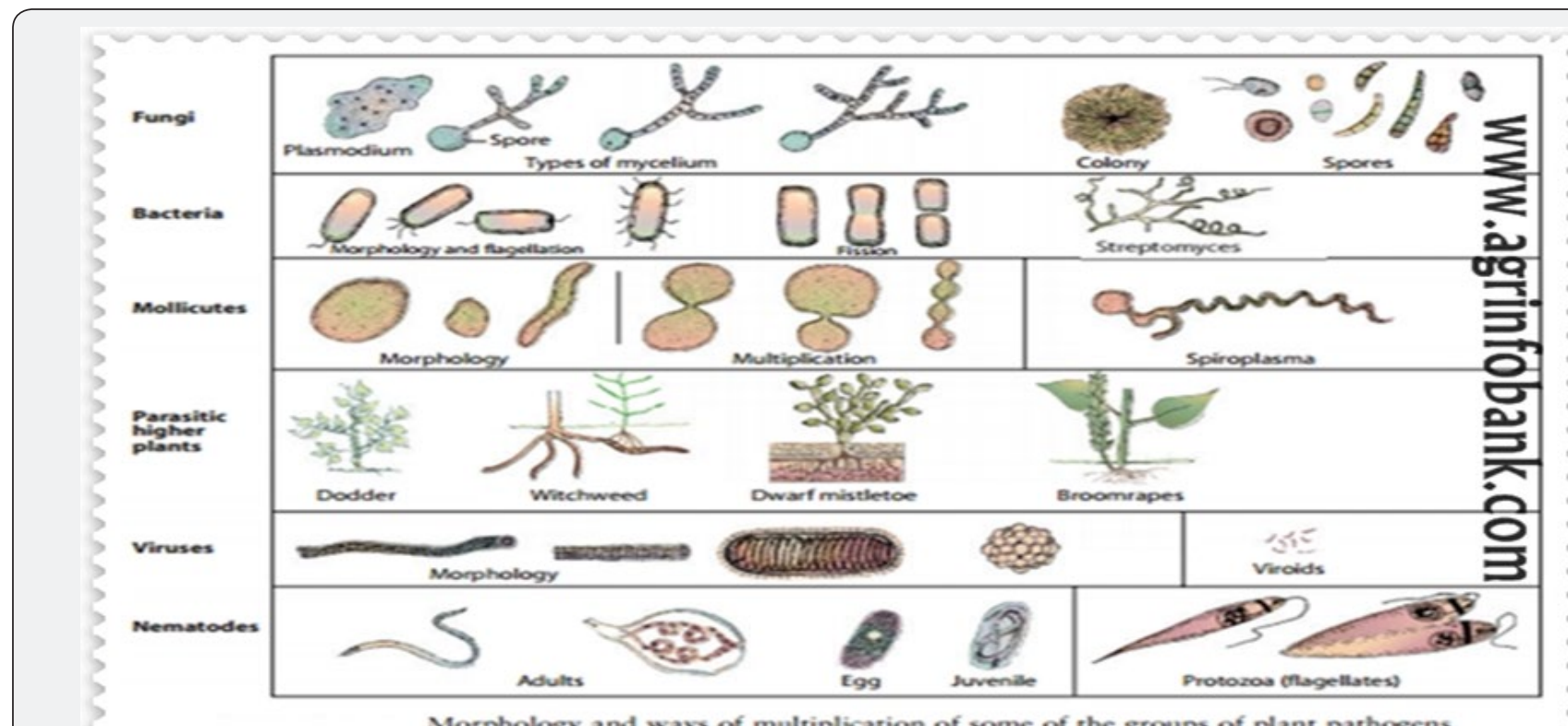

Morphology and ways of multiplication of some of the groups of plant pathogens.

Figure 2: Different kinds of the plant pathogens.

\section{History of the Plant Pathology}

Plant diseases are the very old concepts, even when the primitive man lives on the mercy of the nature and they stared to utilise the plants for there several needs, still that time there was the probability of the plants dieses in any other forms. They effects the seeds, leaves and the fruits and them many other plant parts, however the early civilization was completely devoid of the appearances of the plants dieses due to the proper lacks of the identification of the dieses in that forms. When the early civilization starts to live, they cultivate $\&$ domesticate the plants and the animals for there several purposes respectively. . They cultivate the crops in a plot and then experience the several kinds of the dieses in that cultivation of the crops in several parts of the world as well in the Indus civilization of the India. The oldest testament of the plant pathology was found and it has been recorded in the Homer 1000 B.C. and 750 B.C. They were feared the civilization as the human diseases and the war. Even in the bible also the there was mentioned of the many kinds of the plant diseases. In the Greek philosopher like the Democritus in the $470 \mathrm{BC}$ there was the mentioned of the plant diseases. They describers the plant dieses in the form of the blights. The peoples like the Theophrastus also mentioned the plant diseases. They analyses the plants diseases in the systematic form [1].

Theophrastus wrote the two books on the plant pathology, one of them was the nature of the plants, in this book he describes the all the aspects of the plants world like the morphology, anatomy and the embryology, the another books was the reasons of the vegetable growth, in this books he includes the methods for the propagation of the plants, culture practices and the environmental condition for the propagation of the plants. In this book he mentioned the some of the plant diseases. Theophrastus has been considered as the father of the botany. The theory of the plant diseases and the description of the plant of the Theophrastus were based on the old beliefs and the old theories of those times. The control of the epidemics of the plant dieses was also not possible at that time, since there was lacks of the proper scientific knowledge, so the exact control measures for the control of the plant diseases was not acknowledge at 
that times. Efforts for the control of the plant dieses were also not possible due to the lacks of the knowledge and the lacks of the proper scientific knowledge of the plant diseases. However there are some reports of the control of the plants diseases by the chemical means, in this case the homer utilises the sulphur for the control of the plant dieses and the Theophrastus utilises olive oil for the control of the plant diseases from the extract of the olive oil [2-9].

However in much old belief system they were based on the belief on the god and the many other kinds of the Devi and the Devta of that community and that locality of that era [1]. Hover the exact era of the plant pathology was began from the $1200 \mathrm{AD}$ form the mistletoe research on the plant pathology. Peoples suffer from the hungers and the malnutrition's due to partially to diseases destroy their crops.

However they have not any options except to prey with the god to eradicate the dieses and to reduce the dieses form the society and from the field. In the mid 1600 century, there was the observation of the French farmers that wheat rust dieses was very severs in the place where the Barbary bushes grows nears by, the farmers observation was that the rust was produced in the Barberry plants and from there it moves in to the wheat. So they ask the French government at that time to cut the barberry bushes and passed the legislation to cut the bushes and to control the diseases [1].

In the 1670 the ergot dieses of the grains was observed by the French physician Thoulier and they found that the incidences of the ergot are very common in the peoples who in just the grain infected by the ergot. Later on research in the field of the microscope and in the field of the other branches of the sciences emerged to start and they start the branches of the plant pathology like in the files of the virology, Nematology, bacteria [1]. It was not until the discovery of the concepts of the origin of the species of the charales Darwin of the system nature in which they uses the all the principles of the nature and the natural selection and they revised the all existing principles, theses theories of the Charles Darwin was the changing point of the all the principles of the file sciences [10-13].

The discovery of the microscope and there modification also embarks the era of the new plant pathology. In 1729 the Italian plant pathologist Micheli, describes the new genera's of the fungi and illustrated there reproductive structures. In 1755 the Frenchmen Tillet working on the smutted wheat, and they found that they can increase the number of the wheat plants by the means of the covered smut. He also noted that he can reduce the number of the wheat smut by reducing the smut by the way of the treating the smut by the means of the copperier sulphate. From the 1850 to the era of the 1900 that was the era of the development of plant pathology [14]. In 1800 centuries the diseases of the late blight of the potato was the very important dieses in the changing the pathway of the plant pathology. In addition to that there was many more discovery were made according to the time in the field of the plant pathology [1].

\section{Conclusion}

Overall this is the review articles which shows the some of the aspects of the plant pathology, the era of the plant pathology develops according to the time and they opens the vistas of the new aspects of the life sciences, plant pathology is the very valuable branches and they responsible for the giant growth of the trees and the many more crops of the commercial values.

\section{References}

1. Agrios George N (1972) Plant Pathology. ( $3^{\text {rd }}$ edn), Academic Press Netherlands, Europe.

2. Martinelli F, Scalenghe R, Davino S, Panno S, Scuderi, et al. (2014) Advanced methods of plant disease detection. A review. Agronomy for Sustainable Development 35(1): 1-25.

3. Nicole Davis (2009) Genome of Irish potato famine pathogen decoded. Broad Institute of MIT and Harvard.

4. Kamoun S, Furzer O, Jones JD, Judelson HS, Ali GS (2015) The Top 10 Oomycete pathogens in molecular plant pathology. Mol Plant Pathol 16(4): 413-434.

5. 2010 Scientists discover how deadly fungal microbes enter host cells. Blacksburg, USA.

6. Jackson RW (2009) Plant Pathogenic Bacteria: Genomics and Molecular Biology. Caister Academic Press, UK.

7. Burkholder (1948) Bacteria as Plant Pathogens. Annual Review of Microbiology Cornell University 2: 389-412.

8. (2011) Research team unravels tomato pathogen's tricks of the trade. Virginia Tech, Blacksburg, USA.

9. Creamer R, Hubble H, Lewis A (2005) Curtovirus Infection of Chile Pepper in New Mexico. Plant Diseases 89(5): 480-486.

10. Huynh BL, Matthews WC, Ehlers DJ, Lucas RM, Santos RPJ, et al. (2016) A major QTL corresponding to the Rk locus for resistance to root-knot nematodes in cowpea (Vigna unguiculata L Walp). Theoretical and Applied Genetics 129(1): 87-95.

11. Jankevicius JV, Itow JS, Maeda AL, Campaner M, Conchon I, et al. (1988) Ciclo biológico de Phytomonas/Biological cycle of Phytomonas. Memories of the Oswaldo Cruz Institute Rio de Janeiro, 83 suppl 1.

12. Winbo M (2011) How do plants fight disease? Breakthrough research by UC Riverside plant pathologist offers a clue. UC Riverside.

13. (2011) 1st large-scale map of a plant's protein network addresses evolution, disease process. Dana-Farber Cancer Institute Boston, USA.

14. Aisnworth GC (1981) Introduction to the History of Plant Pathology. Cambridge University Press Med Hist 26(2): 221. 


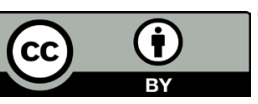

This work is licensed under Creative Commons Attribution 4.0 License

\section{Your next submission with Juniper Publishers will reach you the below assets}

- Quality Editorial service

- Swift Peer Review

- Reprints availability

- E-prints Service

- Manuscript Podcast for convenient understanding

- Global attainment for your research

- Manuscript accessibility in different formats ( Pdf, E-pub, Full Text, Audio)

- Unceasing customer service

Track the below URL for one-step submission https://juniperpublishers.com/online-submission.php 